\title{
Effects of nanoporous anodic titanium oxide on human adipose derived stem cells
}

\author{
This article was published in the following Dove Press journal: \\ International Journal of Nanomedicine \\ 14 October 2016 \\ Number of times this article has been viewed
}

\author{
Katarzyna Malec' \\ Joanna Góralska' \\ Magdalena Hubalewska- \\ Mazgaj $^{2}$ \\ Paulina Głowacz' \\ Magdalena Jarosz $z^{3}$ \\ Pawel Brzewski ${ }^{4}$ \\ Grzegorz D Sulka ${ }^{3}$ \\ Marian Jaskuła ${ }^{3}$ \\ Iwona Wybrańska' \\ 'Department of Clinical Biochemistry, \\ Jagiellonian University Medical \\ College, ${ }^{2}$ Department of Genetic \\ Research and Nutrigenomics, \\ Malopolska Centre of Biotechnology, \\ Jagiellonian University, ${ }^{3}$ Department \\ of Physical Chemistry and \\ Electrochemistry, Faculty of \\ Chemistry, Jagiellonian University, \\ ${ }^{4}$ Department of Dermatology, \\ Jagiellonian University Medical \\ College, Kraków, Poland
}

\begin{abstract}
The aim of current bone biomaterials research is to design implants that induce controlled, guided, successful, and rapid healing. Titanium implants are widely used in dental, orthopedic, and reconstructive surgery. A series of studies has indicated that cells can respond not only to the chemical properties of the biomaterial, but also, in particular, to the changes in surface topography. Nanoporous materials remain in focus of scientific queries due to their exclusive properties and broad applications. One such material is nanostructured titanium oxide with highly ordered, mutually perpendicular nanopores. Nanoporous anodic titanium dioxide $\left(\mathrm{TiO}_{2}\right)$ films were fabricated by a three-step anodization process in propan-1,2,3-triolbased electrolyte containing fluoride ions. Adipose-derived stem cells offer many interesting opportunities for regenerative medicine. The important goal of tissue engineering is to direct stem cell differentiation into a desired cell lineage. The influence of nanoporous $\mathrm{TiO}_{2}$ with pore diameters of 80 and $108 \mathrm{~nm}$ on cell response, growth, viability, and ability to differentiate into osteoblastic lineage of human adipose-derived progenitors was explored. Cells were harvested from the subcutaneous abdominal fat tissue by a simple, minimally invasive, and inexpensive method. Our results indicate that anodic nanostructured $\mathrm{TiO}_{2}$ is a safe and nontoxic biomaterial. In vitro studies demonstrated that the nanotopography induced and enhanced osteodifferentiation of human adipose-derived stem cells from the abdominal subcutaneous fat tissue.
\end{abstract}

Keywords: adipose-derived stem cells, anodic titanium oxide, nanotopography, osteogenic differentiation, biomaterials

\section{Introduction}

The aim of current bone biomaterials research is to design implants that induce controlled, guided, successful, and rapid healing. Titanium (Ti) implants and its alloys are widely used in dental, orthopedic, and reconstructive surgery. The popularity of this biomaterial is a consequence of extraordinary constellation of physical and chemical properties. Ti has a relatively low density $\left(4.5 \mathrm{~g} / \mathrm{cm}^{3}\right)$ in comparison to other metals; hence, the structures made from it are light and retain the strength and toughness. Ti implants possess high corrosion resistance in human body and low thermal conductivity, which reduce the risk of thermal injury of tissues during implantation.

A series of studies has indicated that cells can respond not only to the chemical properties of the biomaterial, but also, in particular, to the changes in the surface topography, roughness, and energy. ${ }^{1}$ Various experiments indicate that cells respond to the modifications in the surface topography through changes in adhesion, proliferation, morphology, and differentiation. ${ }^{2,3}$ Through controlled surface modifications of the implant, cell behavior, cytoskeletal organization, and gene expression can be regulated (contact guidance). Numerous studies have proved that the osteoblastic cells are better adapted to a nanoscale environment rather than to microscale niche.,
Correspondence: Katarzyna Malec Department of Clinical Biochemistry, Jagiellonian University Medical College, UI Kopernika I5A,

3I-50I Kraków, Poland

$\mathrm{Tel}+48$ I2 608589386

Fax +48 I2 4214073

Email malec.katarzyna@gmail.com (c)
hereby accept the Terms. Non-commercial uses of the work are permitted without any further permission from Dove Medical Press Limited, provided the work is properly attributed. For permission hereby accept the Terms. Non-commercial uses of the work are permitted without any further permission from Dove Medict
for commercial use of this work, please see paragraphs 4.2 and 5 of our Terms (https://www.dovepress.com/terms.php). 
Nanomaterials are structures constructed of elements (rods, grains, pores, fibers, tubes, etc) the size of which is in the range of $1-100 \mathrm{~nm} .{ }^{5,6}$ Small surface particles result in a good ratio of surface to material volume, improved electrical, thermal, and ionic conductivity, and greater surface catalytic activity. ${ }^{7}$ It has been proved that biomaterials with nanoparticles can interfere with biologic mechanisms at the molecular level and through the architectonic resemblance to natural tissues (especially the extracellular matrix), can stimulate cell growth and proliferation and reduce unfavorable immunological reactions. ${ }^{8}$ One of the attractive applications of nanostructured implants is guided bone regeneration.

Among the various methods of creating nanotopography, anodic oxidation of $\mathrm{Ti}$ and Ti-based alloys is receiving much attention because of its relative simplicity and economic attractiveness. In the year 1999, Zwilling et al were the first to report the self-ordered nanostructured titanium dioxide $\left(\mathrm{TiO}_{2}\right)$ obtained by electrochemical anodization in fluoride-containing electrolyte. ${ }^{9}$ Subsequent publications have proven that the controlled anodic oxidation in fluoride-containing electrolytes can produce highly ordered coatings of $\mathrm{TiO}_{2}$ nanotubes or nanopores. ${ }^{10-12}$ By manipulating the electrochemical parameters of the anodization process (temperature, applied potential, $\mathrm{pH}$, composition and concentration of the electrolyte, duration, viscosity, etc), morphology and geometrical properties (pore/tube diameter, inter-pore spacing, thickness, etc) of anodic titanium oxide (ATO) can be tailored. ${ }^{12-14}$ Extremely smooth, regular, and ordered tubes are achieved by three-step anodization of pure $\mathrm{Ti}$ in viscous, organic electrolytes such as ethylene glycol and glycerol. ${ }^{15,16}$

The capacity of the biomaterial to stimulate the osteogenic differentiation of mesenchymal stem cells (MSCs) is crucial for effective osseointegration and successful bone healing. ${ }^{17,18}$ One of the attractive and promising sources of mesenchymal progenitors is stromal vascular fraction (SVF) of the adipose tissue. The SVF is a jumble of heterogeneous cell populations, including blood cells, fibroblasts, pericytes, endothelial cells, adipocyte progenitors, and multipotent undifferentiated cells (adipose-derived stem cells [ASCs]). ${ }^{19,20}$

ASCs have pluripotent differentiation capacity comparable to bone marrow-derived stem cells and are relatively easily accessible with great abundance and lower donor site morbidity. ${ }^{18}$ A series of studies has confirmed that ASCs have multipotent capacity to differentiate toward various cell lineages: osteogenic, adipogenic, chondrogenic, and myogenic, depending on the presence of specific induction factors. ${ }^{19-22}$ The important goal of tissue engineering is to direct the differentiation of stem cells into a specific desired phenotype.

In vitro experiments with human mesenchymal progenitors and biomaterials provide valuable information about cell behavior and its interactions with the material, which can be beneficial for applications in clinical practice in future.

\section{Experimental Scaffold preparation}

Electrochemical oxidation has been used to fabricate the nanoporous oxide layer. A Ti foil ( $99.6 \%$ purity; Goodfellow) of $0.1 \mathrm{~mm}$ thickness was precut in square coupons $(1 \times 1 \mathrm{~cm})$ and degreased in acetone and ethanol. Prior to anodization process, the Ti samples were both electrochemically and chemically polished. The electrochemical polishing was performed in a mixture of $120 \mathrm{~mL}$ of acetic acid (98 wt.\%), $30 \mathrm{~mL}$ of hydrofluoric acid (40 wt. \%), and $50 \mathrm{~mL}$ of sulfuric acid (98 wt.\%) at a constant current density of $1.4 \mathrm{~A} / \mathrm{cm}^{2}$ at $20^{\circ} \mathrm{C}$ for 60 seconds. Then, the Ti samples were immersed in a solution of $40 \mathrm{wt} . \%$ of $\mathrm{HF}$ and $65 \mathrm{wt} . \%$ of $\mathrm{HNO}_{3}(1: 3)$ for 10 seconds at $20^{\circ} \mathrm{C}$, washed in water and ethanol, and air-dried.

ATO layers were obtained by a three-step anodization process in glycerol (propan-1,2,3-triol) solution with $\mathrm{NH}_{4} \mathrm{~F}\left(0.38\right.$ wt.\%) and $\mathrm{H}_{2} \mathrm{O}(1.79$ wt.\%). The anodization was conducted in a two-electrode configuration with the $\mathrm{Ti}$ sample as the anode and a platinum mesh as the cathode in electrochemical cells. The ATO layers were fabricated at a constant anodizing potential of $40 \mathrm{~V}$ for $\sim 80 \mathrm{~nm}$ pore dimension and $50 \mathrm{~V}$ for $\sim 108 \mathrm{~nm}$ pore dimension at a temperature of $20^{\circ} \mathrm{C}$. The duration of the first and second steps was 3 hours. The third step was carried out for 1 hour. After the first and second steps, the ATO layers were mechanically removed from Ti surface and the samples were immediately reanodized. ${ }^{14,23,24}$ After the third oxidation step, the samples were rinsed with water, air-dried, and sterilized by ethylene oxide. The structure and morphology of fabricated ATO samples were verified by a field emission scanning electron microscope (FE-SEM; Hitachi S-4700). For the experiments, four different categories of Ti samples were used: nanoporous Ti with a pore diameter of $\sim 80 \mathrm{~nm}(80 \mathrm{~nm})$, nanoporous $\mathrm{Ti}$ with a pore diameter of $\sim 108 \mathrm{~nm}(108 \mathrm{~nm})$, electrochemically polished Ti surface (W), and standard, untreated Ti sample (S) as a control.

\section{Isolation of MSCs}

SVF was obtained from the fatty portion excised from the abdominal subcutaneous fat tissue of patients undergoing 
elective abdominal surgery after receiving their written informed consent.

Human ASCs were obtained from SVF according to the previously described method. ${ }^{25,26}$ Briefly, the fatty portion was minced mechanically, and purified of contaminating debris of vessels, connective tissue, and blood clots and treated with $200 \mathrm{U} / \mathrm{mL}$ collagenase type IA $0.1 \%$ (Sigma). The suspension was centrifuged and filtered through 100 and $40 \mu \mathrm{m}$ cell strainers to eliminate the debris (Figure 1). Top lipid layer was discarded; the remaining cells were resuspended in the culture medium and plated onto conventional culture flasks. ADSCs were passed under the same conditions $\left(37^{\circ} \mathrm{C}, 5 \% \mathrm{CO}_{2}\right.$, humidity $95 \%$ ), and the confluent $(70 \%)$ cell cultures were split with $0.25 \%$ trypsin-ethylenediaminetetraacetic acid (Sigma). The cells of the sixth passage were used for the experiments. The Bioethics Committee of Jagiellonian University (KBET/354/B/2012) approved all the procedures.

\section{Cell culture}

Cells were grown on $1 \mathrm{~cm}^{2}$ Ti samples in 12-well culture plates in the osteogenic medium (medium R) containing basal culture medium supplemented with $0.1 \mu \mathrm{M}$ dexamethasone (Sigma), $50 \mu \mathrm{M}$ ascorbate-2-phosphate (Sigma), $10 \mathrm{mM}$ $\beta$-glycerol phosphate (Sigma), and $0.01 \mu \mathrm{M} 1.25(\mathrm{OH})_{2} \mathrm{D}_{3}$ (Sigma). ${ }^{20,21,27}$ The same medium was used with all $\mathrm{Ti}$ samples. As a control, the ASCs were plated in 12-well culture plates, without Ti samples, in osteogenic medium. There was also control cell culture of ASCs in polystyrene culture dish, without Ti samples, in basal culture medium (medium B). All cells were plated at a density of $10^{4}$ cells $/ \mathrm{cm}^{2}$. The media were refreshed twice a week. Cells were cultured for 21 days.

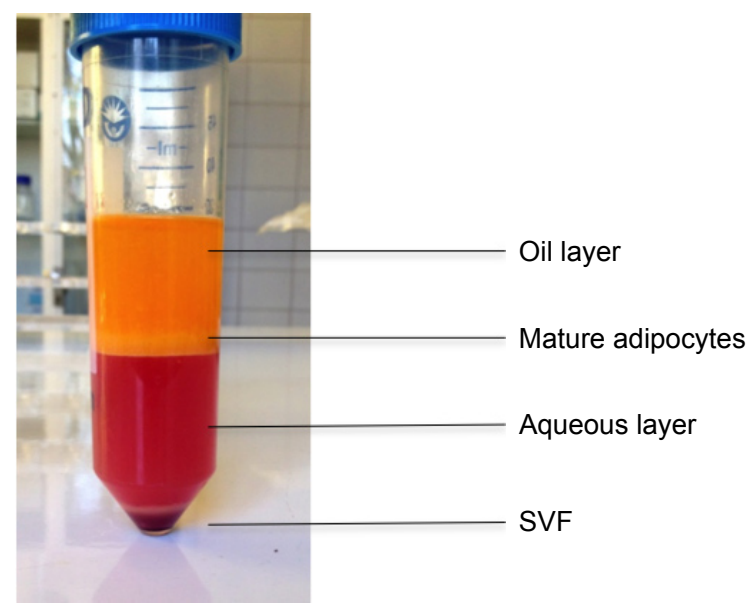

Figure I SVF isolation.

Abbreviation: SVF, stromal vascular fraction.

\section{Cell viability}

To estimate the cytotoxicity of Ti nanoporous samples, extracellular lactate dehydrogenase (LDH) activity was measured using CytoTox 96 NonRadioactive Cytotoxicity Assay (Promega Corporation, Fitchburg, WI, USA) according to the manufacturer's instructions. ${ }^{28}$ Activity of extracellular LDH was assessed 24 hours after the replacement of the culture medium at day 1 and day 21. Absorbance was measured at $490 \mathrm{~nm}$. The amount of color formed is proportional to the number of lysed cells. ${ }^{29}$

\section{Cell proliferation}

After 1, 4, and 14 days of incubation, proliferation was investigated with Cell Proliferation ELISA, BrdU kit (Hoffman-La Roche Ltd.) according to the manufacturer's protocol. Absorbance was measured at $450 \mathrm{~nm}$.

\section{Gene expression}

Expression of the genes alkaline phosphatase (ALPL), Runx-2 transcription factor, osteocalcin (BGLAP), Osterix transcription factor $(S P 7)$, bone morphogenetic protein 2 (BMP2K), T-box transcription factor (TBX3), and osteonectin $(S P A R C)$ was quantified in cells lysed from each Ti sample. Gene expression was determined by real-time polymerase chain reaction (RT-PCR). ${ }^{30,31}$ Briefly, total RNA was isolated from the cells using TRIzol Reagent (Thermo Fisher Scientific) according to the method previously described by Chomczyński and Sacchi. ${ }^{32}$ Total RNA was extracted with the commercial assay Pure Link RNA Mini Kit (Thermo Fisher Scientific) after 1, 7, 14, and 21 days of experiment according to the manufacturer's instructions. Subsequently, quantification and quality control of isolated RNA were performed (by measuring the absorbance at 230 and 260 $\mathrm{nm})$. Oligonucleotides for the chosen genes were synthesized with a two-step quantitative RT-PCR technique. The collected RNA was reverse transcribed to complementary DNA (cDNA) using High-Capacity RN-to-cDNA Kit (Thermo Fisher Scientific) in accordance with the attached protocol. Subsequently, the cDNA was amplified and its expression measured by real-time PCR with TaqMan Gene Expression Assay (Thermo Fisher Scientific). The amplification was completed using QuantStudio 12K Flex Real-Time PCR System (Applied Biosystems). Forty cycles of PCR were run: activation of uracil-DNA glycosylase at $50^{\circ} \mathrm{C}$ for 120 seconds, AmpliTaqGold polymerase activation at $90^{\circ} \mathrm{C}$ for 600 seconds, denaturation at $95^{\circ} \mathrm{C}$ for 15 seconds, and annealing/elongation at $60^{\circ} \mathrm{C}$ for 60 seconds. Nontemplate controls were used in each experiment to supervise the purity 
of samples. All experiments were performed in triplicate for each tested sample and for each gene. A comparison test of cycle threshold points was used to quantify the gene expression for each sample. Results were normalized to the expression of housekeeping gene $A C T B$ ( $\beta$-actin). Gene expression levels were expressed as a relative fold change to the expression of cells cultured on the untreated Ti surface. ${ }^{33,34}$

\section{Alizarin red $\mathrm{S}$ staining}

For identification of calcification, alizarin red staining was performed after 21 days of cell culture. The mineralization assay was investigated on each substrate. Cell cultures were fixed in 4\% paraformaldehyde for 5 minutes at room temperature and stained with fresh $2 \%$ aqueous solution of alizarin red S (Sigma). For the quantitative evaluation of mineralized calcium, the samples were incubated in 10\% acetic acid for 30 minutes. Cells were scraped from the Ti surfaces and centrifuged in acetic acid for 30 seconds. The samples were then boiled at $85^{\circ} \mathrm{C}$ for 10 minutes and incubated on ice for 5 minutes. The samples were neutralized with 10\% ammonium hydroxide and centrifuged for 15 minutes at $20,000 \times g$. Absorbance was measured at $405 \mathrm{~nm} .{ }^{35}$ Calibration curves of 0.039-10 mM served for calculation of calcium concentration. Results were normalized with respect to total protein level measured using Lowry-Peterson method (Total Protein Kit, Micro Lowry, Peterson's Modification; Sigma). ${ }^{36-38}$

\section{SEM analysis}

After period of 21 days, three samples of each type were washed with phosphate-buffered saline (PBS) and fixed in $2.5 \%$ glutaraldehyde (Polysciences, Inc.) in $0.1 \mathrm{M}$ phosphoric buffer for 24 hours ( $\mathrm{pH}=7.4$, room temperature). Samples were dehydrated in a graded series of ethanol $(50 \%, 60 \%$, $70 \%, 80 \%, 90 \%, 99.8 \%$ ) for 10 minutes each and left in $99.8 \%$ alcohol until they were dried in supercritical point $\mathrm{CO}_{2}$ (E3000; Quorum Technologies). The dried samples were sputter-coated with gold by coater JEOL JFC-1100E. The morphology of the $\mathrm{TiO}_{2}$ nanopores and the adhered cells was visualized using a Hitachi S-4700 SEM at an accelerating voltage of $10-20 \mathrm{kV}$.

\section{Statistical analysis}

All experiments were run in triplicate. Cell culture experiments were repeated three times using three samples per group. Results are expressed as a mean with standard deviation of the mean. Statistical analysis was performed with Student's $t$-test and analysis of variance (Statistica 10.0) and considered significant when $P<0.05$.

\section{Results and discussion Cell characterization}

Cells were isolated from the fatty portion excised from the abdominal subcutaneous fat tissue. Adipose tissue was obtained from 10 patients ( 5 male and 5 female) undergoing elective abdominal surgery (five inguinal hernia repair, one umbilical hernia repair, one repair of the linea alba hernia, four skin naevi excision). Age of the patients ranged between 21 and 59 with a mean of $41.9( \pm 11.97)$.

\section{Surface characterization of $\mathrm{Ti}$ and $\mathrm{TiO}_{2}$ samples}

Random samples were taken from each category. The morphology of Ti samples was characterized by SEM to examine the geometric parameters of the nanostructures. SEM analysis confirmed the presence of nanoporous films on the samples treated with three-step anodic oxidation procedure. Nanopores were smooth, highly ordered, uniformly covering the metal surface, and arranged in a honeycomb structure.

The pore diameters were $\sim 80 \mathrm{~nm}(40 \mathrm{~V})$ and $108 \mathrm{~nm}$ $(50 \mathrm{~V})$. The interpore distance was $151.78 \pm 10.74$ for the anodization potential of $40 \mathrm{~V}$ and $233.61 \pm 27.48$ for $50 \mathrm{~V}$. The thickness of the nanotubular layer after three-step anodic oxidation was $\sim 500 \mathrm{~nm}$. Geometric parameters are presented in Table 1, and Figure 2 shows the plain and nanocoated Ti surfaces.

\section{Cell viability}

The results are presented as the percent of the control. The standard, unmodified Ti surface $(\mathrm{S})$ and cells in basic culture medium (medium B) were chosen as a reference.

Table I Structural parameters of anodic $\mathrm{TiO}_{2}$ obtained at different applied potentials

\begin{tabular}{|c|c|c|c|}
\hline $\begin{array}{l}\text { Applied } \\
\text { potential (V) }\end{array}$ & $\begin{array}{l}\text { Pore } \\
\text { diameter }(\mathrm{nm})\end{array}$ & $\begin{array}{l}\text { Interpore } \\
\text { distance }(\mathbf{n m})\end{array}$ & $\begin{array}{l}\text { Thickness of nanoporous } \\
\text { layer }(\mathrm{nm})\end{array}$ \\
\hline 40 & $79.36 \pm 0.43$ & $151.78 \pm 10.74$ & $505 \pm 39$ \\
\hline 50 & $107.89 \pm 15.11$ & $233.61 \pm 27.48$ & $555 \pm 76$ \\
\hline
\end{tabular}



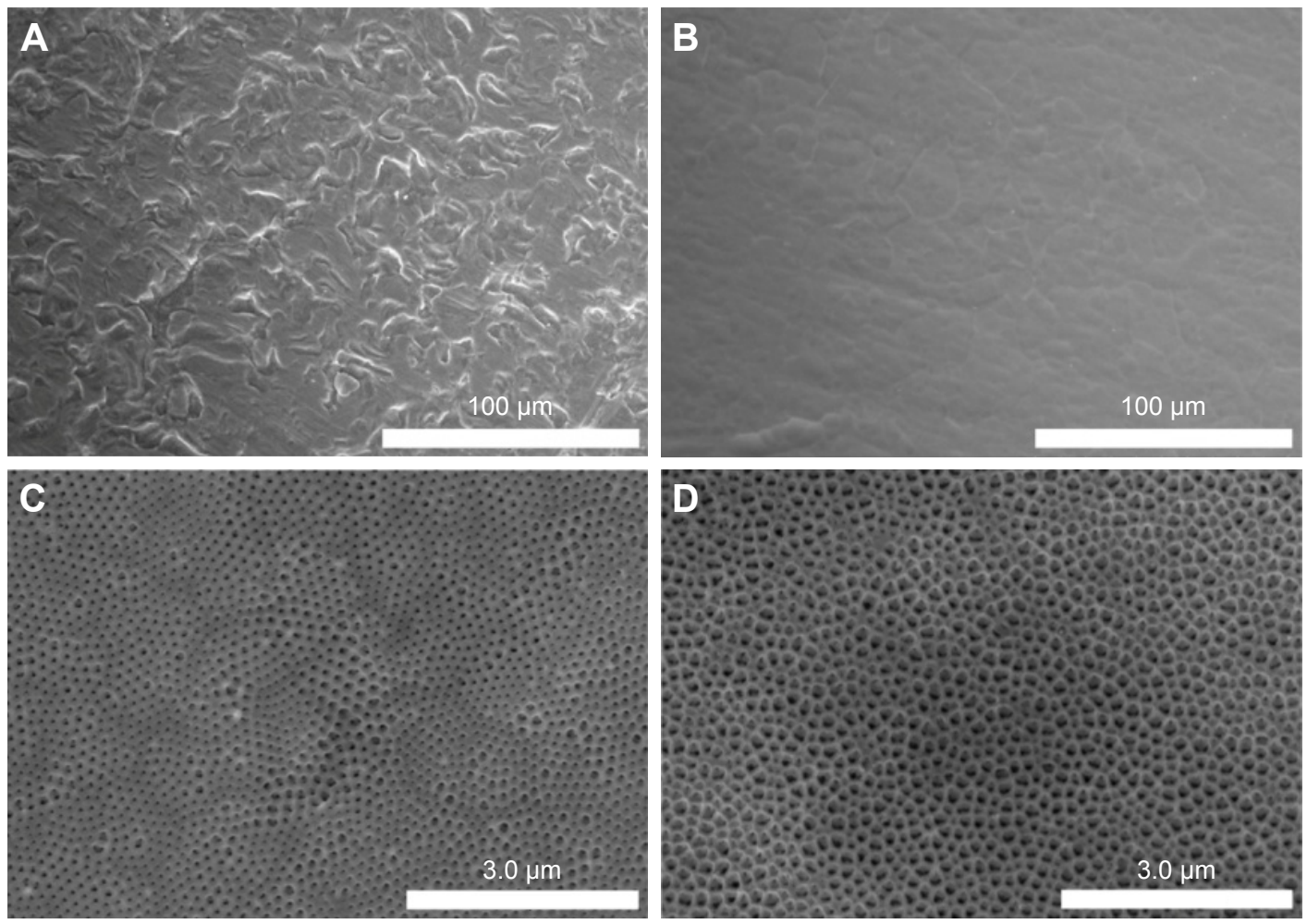

Figure 2 Scanning electron microscopy images of Ti samples.

Notes: (A) Standard, untreated $\mathrm{Ti}$ sample; (B) electropolished $\mathrm{Ti}$ sample; (C) nanoporous $\mathrm{TiO}_{2}$ on $\mathrm{Ti}$ foil with pores $\sim 80 \mathrm{~nm}$; (D) nanoporous $\mathrm{TiO}{ }_{2}$ on $\mathrm{Ti}$ foil with pores $\sim 108 \mathrm{~nm}(500 \times$ magnification).

LDH release measured on both nanoporous samples was similar to that of the control - no cytotoxic effects were observed. No differences were found between the particular $(1,14,21$ days) culture periods $(P<0.05)$. The results are shown in Figure 3.

\section{Cell proliferation}

Cell proliferation was evaluated by the incorporation of BrdU during the synthesis of DNA chains. On all tested
Ti surfaces, proliferation was the highest at the beginning of the experiment (day 1) and significantly reduced on day 4 ( $P$-value for comparison: 1 day vs 4 days $<0.001 ; 1$ day vs 14 days $<0.001$ for all categories of Ti samples). The extinctions determined for electrochemically polished $\mathrm{Ti}$ samples were significantly lower (on days 1 and 4), when compared to the standard, untreated Ti surface. No statistical differences were found between the two nanoporous samples at any time point (Figure 4).
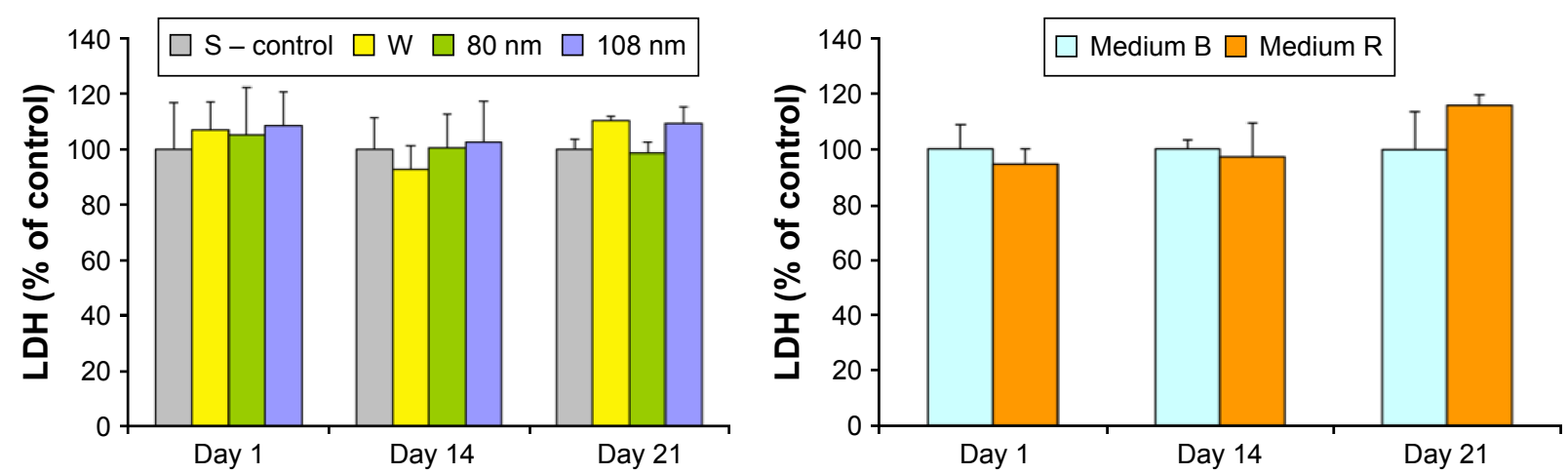

Figure $3 \mathrm{LDH}$ release of cell cultures incubated with four different Ti samples and in two types of medium. Untreated Ti and cell culture in basal medium served as a control. $80 \mathrm{~nm}$, nano- $\mathrm{TiO}_{2}$ with pores $\sim 80 \mathrm{~nm}$; $108 \mathrm{~nm}$, nano- $\mathrm{TiO}_{2}$ with pores $\sim 108 \mathrm{~nm}$.

Abbreviations: LDH, lactate dehydrogenase; medium B, basal culture medium; medium R, osteogenic medium; $\mathrm{S}$, untreated Ti sample; W, electropolished Ti. 


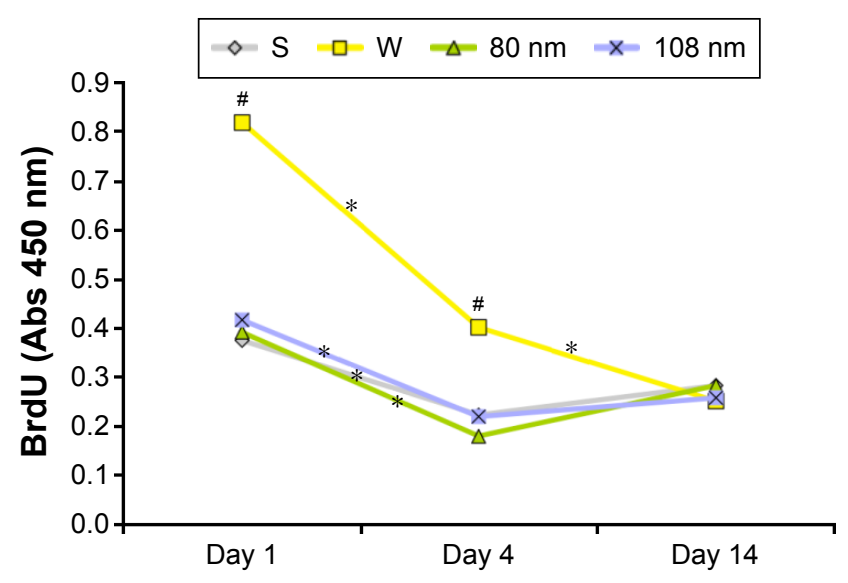

Figure 4 Results of BrdU incorporation test.

Notes: $* P<0.005$ for comparison of extinction between different time points; ${ }^{\#} P<0.005$ for comparison of extinction with untreated $\mathrm{Ti}$ at the same time point. $80 \mathrm{~nm}$, nano- $\mathrm{TiO}_{2}$ with pores $\sim 80 \mathrm{~nm}$; $108 \mathrm{~nm}$, nano- $\mathrm{TiO}_{2}$ with pores $\sim 108 \mathrm{~nm}$. Abbreviations: $\mathrm{S}$, untreated Ti sample; $\mathrm{W}$, electropolished $\mathrm{Ti}$.

\section{Differentiation in gene expression}

Gene expression for osteogenic-related genes, that is, $A L P L$, Runx2, BGLAP, SP7, BMP2K, TBX3, and SPARC, was evaluated. Relative messenger RNA (mRNA) expression was presented as a fold change compared to the expression measured on day 1 on untreated, standard Ti surface or in cells cultured in basic culture medium, respectively. After 14 days, the relative expression of $A L P L$ in cells cultured in osteogenic medium was significantly $(P<0.05)$ higher ( $16 \times$ fold change) than in cells cultured only in basic culture medium. Data from PCR analysis showed higher expression of mRNA osteogenic markers, that is, alkaline phosphatase $(A L P L)$, osteocalcin $(B G L A P)$, and transcription factors (Runx2), in ASCs cultured in osteogenic medium compared to those cultured in basic culture medium at all time points (Figure 5).

Despite the lack of statistical significance, $A L P L$ expression was slightly higher on nanoporous surfaces on the initial days of culture. At all time points, the expression of $T B X 3$ and $R U N X 2$ transcription factors was found on all Ti samples. Nevertheless, the statistical analysis did not show significant differences between the Ti surfaces.

RT-PCR analysis demonstrated that the nanopore caused slight, but statistically significant changes in Osterix transcription factor (SP7) expression. Although there were no significant differences in the expression of mRNA for bone morphogenetic protein $(B M P 2 K)$ and osteonectin (SPARC) on different Ti samples, higher relative values were observed at days 14 and 21 on the nanoporous surfaces. At day 21, greater expression of osteocalcin (BGLAP) was found on nano- $\mathrm{TiO}_{2}$ with pores of $108 \mathrm{~nm}$ (Figure 6).

\section{Alizarin red $\mathrm{S}$ staining}

The results of alizarin assay displayed positive red staining for all Ti surfaces. Macroscopic observations revealed more intensive red tints on nanoporous samples at day 21 (Figure 7). Quantitative analysis of calcium deposition
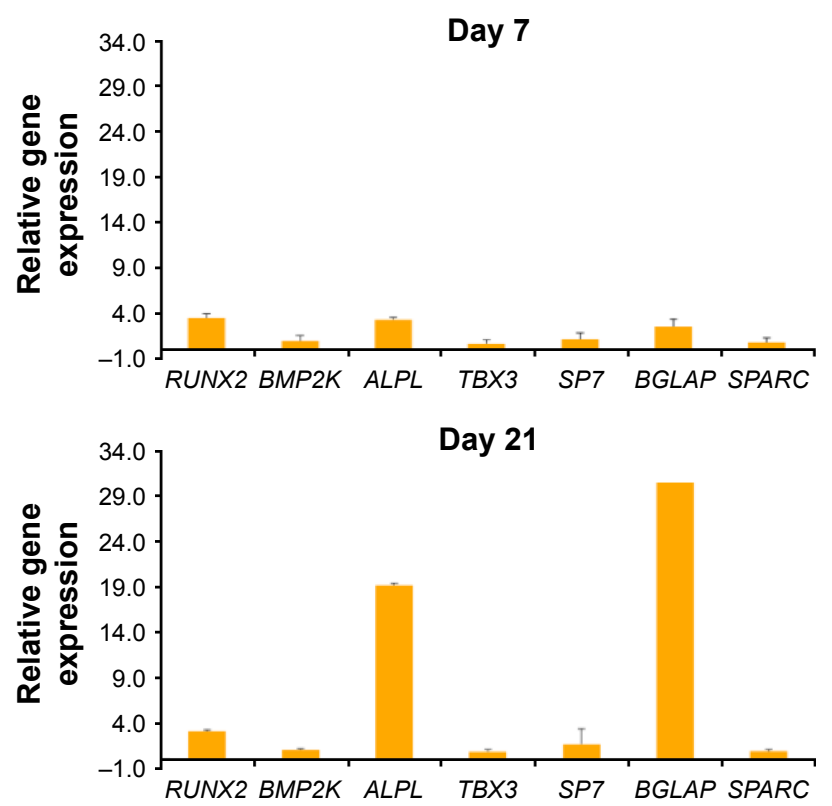

Figure 5 Human osteogenic markers.

Notes: Polymerase chain reaction array results for adipose-derived stem cells cultured in the osteogenic medium without Ti samples. The results are expressed as a fold change compared to the expression measured on day I in cells cultured in basal culture medium. 

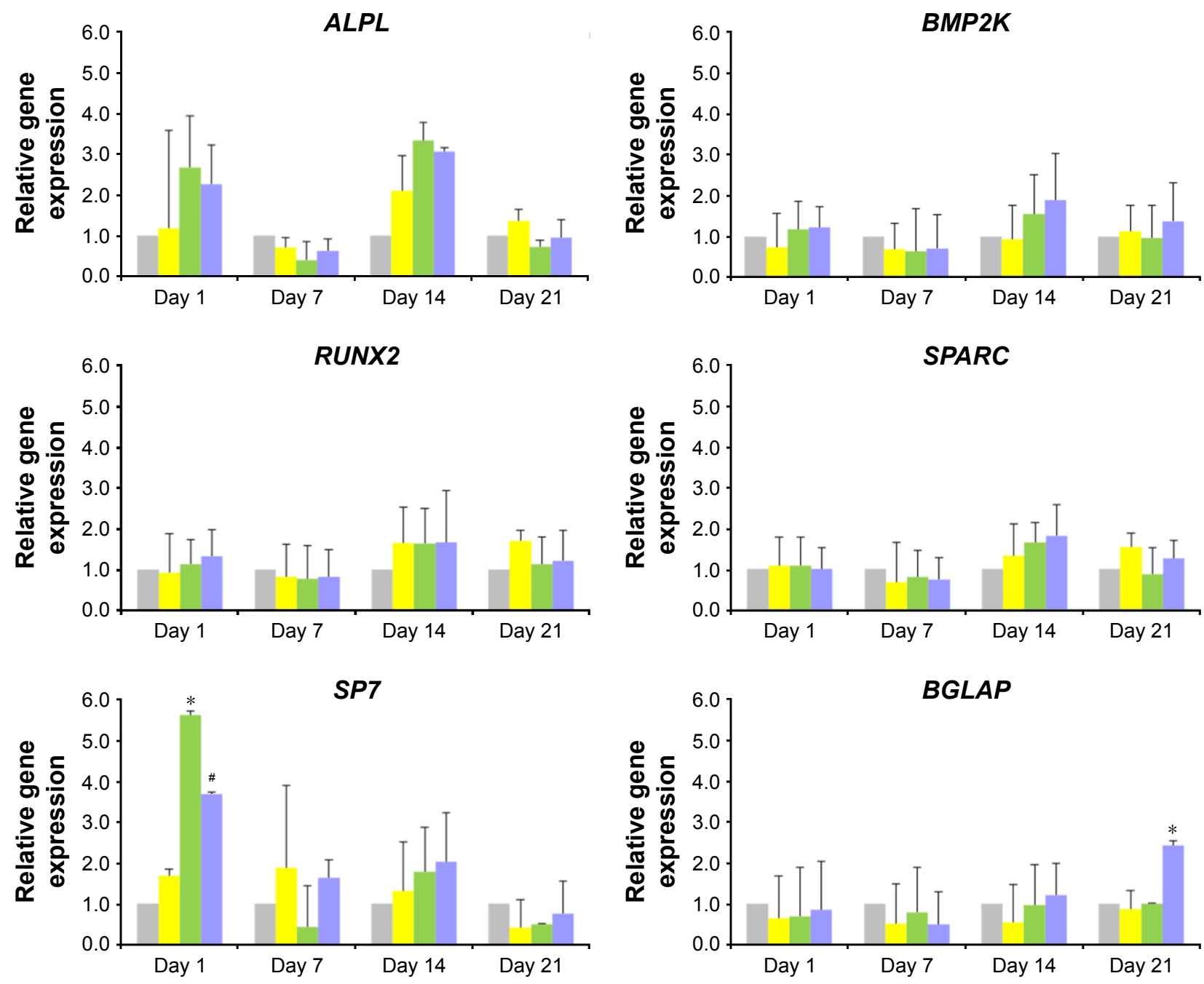

$\square \mathrm{S} \square \mathrm{W} \square 80 \mathrm{~nm} \square 108 \mathrm{~nm}$

Figure 6 Effects of nanostructured Ti on the mRNA expression of selected genes involved in osteogenic differentiation in human adipose-derived stem cells culture. Notes: ${ }^{*} P<0.005$ for the comparison of fold change with untreated $\mathrm{Ti}$ at the same time point; ${ }^{P}<0.005$ nano- $\mathrm{TiO}_{2} 80 \mathrm{~nm}$ versus nano-TiO, $108 \mathrm{~nm}$. $80 \mathrm{~nm}$, nano- $\mathrm{TiO}$, with pores $\sim 80 \mathrm{~nm} ; 108 \mathrm{~nm}$, nano- $\mathrm{TiO}_{2}$ with pores $\sim 108 \mathrm{~nm}$.

Abbreviations: $\mathrm{S}$, untreated $\mathrm{Ti}$ sample; $\mathrm{W}$, electropolished $\mathrm{Ti}$.
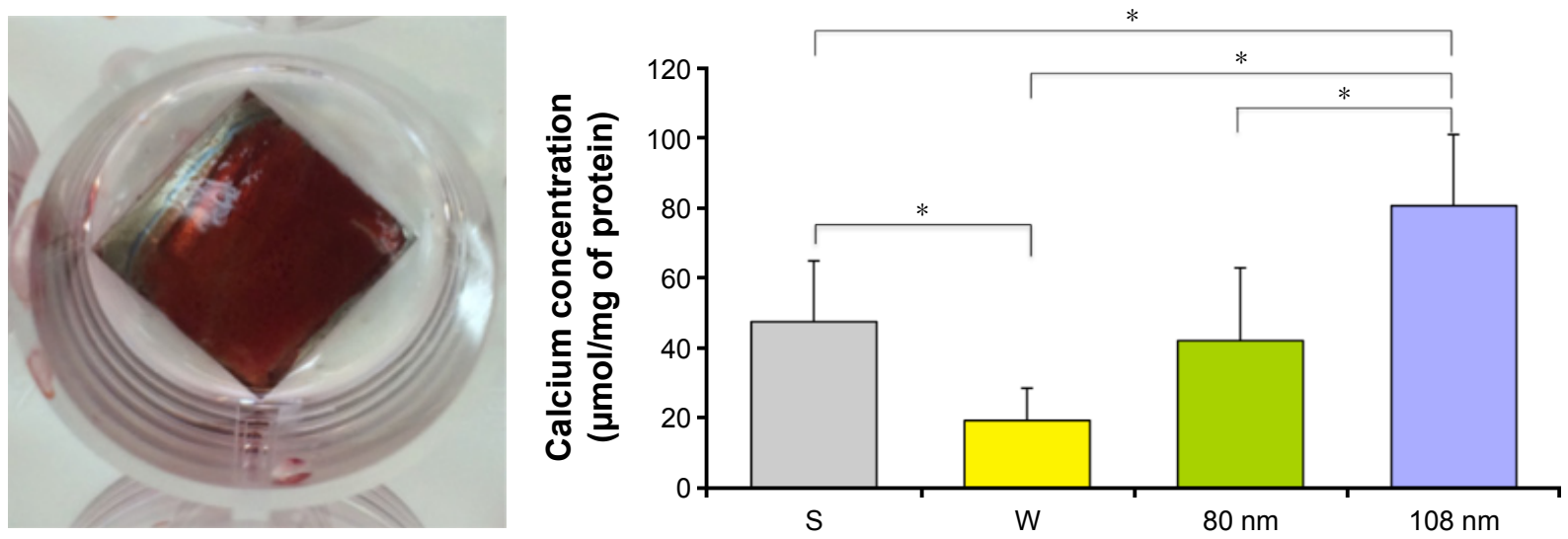

Figure 7 Alizarin red S staining for calcium deposition by human adipose-derived stem cells cultured on Ti surfaces for 21 days; macroscopic observation and results of quantitative analysis normalized to protein content.

Notes: ${ }^{*} \mathrm{P}<0.005 .80 \mathrm{~nm}$, nano- $\mathrm{TiO}_{2}$ with pores $\sim 80 \mathrm{~nm}$; $108 \mathrm{~nm}$, nano- $\mathrm{TiO}_{2}$ with pores $\sim 108 \mathrm{~nm}$.

Abbreviations: $\mathrm{S}$, untreated Ti sample; $\mathrm{W}$, electropolished $\mathrm{Ti}$. 

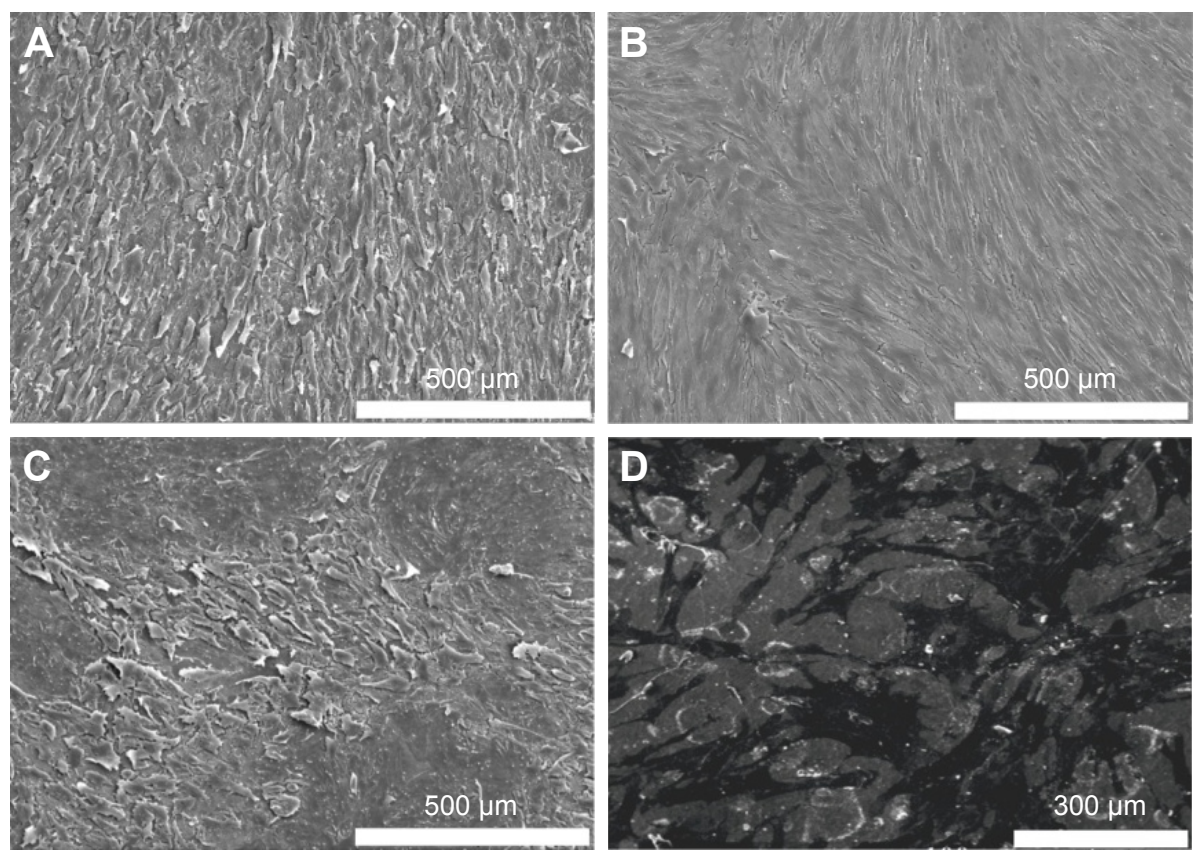

Figure 8 Scanning electron microscopy images of human adipose-derived stem cells cultured on four different Ti surfaces for $2 \mathrm{I}$ days. Notes: (A) Untreated Ti; (B) electropolished Ti; (C and D) nano- $\mathrm{TiO}_{2}$.

showed significantly higher extinctions measured on nano$\mathrm{TiO}_{2}$ with pores of $108 \mathrm{~nm}$ diameter after 21 days of culture than on any other Ti sample. Significantly lower mineral deposits were adsorbed on electropolished sample (W) than on standard, untreated Ti surface. The results are shown in Figure 7.

\section{SEM analysis}

The morphology of ASCs on Ti surfaces was investigated using SEM after 21 days of culture. After 3 weeks of culture, the surface was almost covered by cells. The shapes of the cells cultured on different Ti samples varied noticeably. Cells on untreated Ti surface were tightly and parallelly arranged with an elongated morphology, and were sparsely present as short and poorly developed protrusions (Figure 8). ASCs on nano- $\mathrm{TiO}_{2}$ formed a network of spindle-shape cells communicating with long protrusions (Figure 8). Cellular bodies were flat, stretched, and adhered tightly to the surface. High-magnification SEM images revealed the presence of numerous ASC extensions - filopods - which were greater than the cell body diameter, protruding and anchoring in the pores of nanostructured Ti (Figure 9A). Under high magnification, the granular material adsorbed on nano- $\mathrm{TiO}_{2}$ can be observed which can be mineralized matrix components (Figure 9B). Also, it could be noted that the nanoporous architecture was regular and unchanged even after 21 days of cell culture.
A combination of nanotechnology and stem cell biology might boost the therapeutic benefits and reduce the side effects of stem cell therapies. Nanoscience enriches tissue regeneration possibilities with nanostructures that might act as a three-dimensional scaffold for cells and growth factors.

A particularly attractive method for generation of nanostructures is the controlled anodization of $\mathrm{Ti}$ in fluoridecontaining electrolytes. For this experiment, the three-step anodization method described in detail by Macak and Schmuki was chosen to produce extremely smooth, regular, and highly ordered nanopores. The presence of fluoride ions in the electrolyte enables the formation of soluble metalfluoride complexes. ${ }^{15}$ These protect against the formation of a continuous layer of metal oxide at the bottom of the nanotubes, and small $\mathrm{F}^{-}$ions compete with oxide anion in migration through the oxide layer. As a consequence, at the metal/oxide interface, a discontinuous layer of fluoride ions
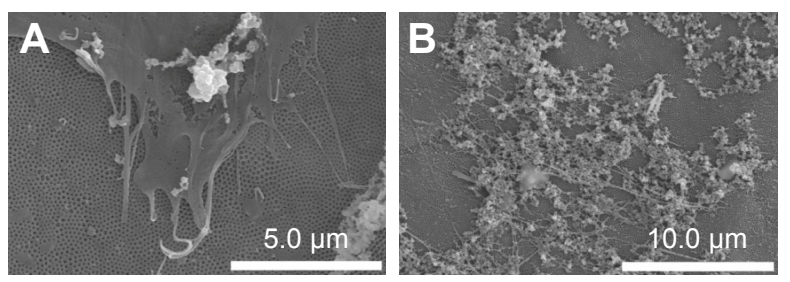

Figure 9 Scanning electron microscopy images of human adipose-derived stem cells cultured on nanoporous $\mathrm{TiO}_{2}$ with a pore diameter of $\sim 108 \mathrm{~nm}$ (A: magnification 10,000x, B: magnification 5,000×). 
is formed and nanotubes are separated., ${ }^{9,39-41}$ The parameters of the anodic oxidation were established to obtain nanoporous oxide with pore diameters of 80 and $108 \mathrm{~nm} \cdot{ }^{14,23,24}$ A possible threat to this method is the risk of pollution to nanoporous film with fluoride residues, which can be harmful for the cultured cells. ${ }^{42}$ In the literature, there are only a few publications about the negative effects of nanoparticles, but these are related to loose grains rather than solid layers, which appear to be the ATO film (even after 21 days of cell culture). ${ }^{43,44}$ Nevertheless, no cytotoxic effects were observed in our experiments.

Most of the published studies examined the osteogenic potential on implant surfaces in vitro by using commercial cell lines ${ }^{45-49}$ or animal cell lines, ${ }^{42,50-56}$ which provide only indirect information on the possible interaction of the scaffold with human cells. According to Rebelatto et al, cells harvested from various sources may present phenotypic heterogeneity and diverse in vivo results after transplantation. ${ }^{55}$ Moreover, most of the studies explore the behavior of immature osteoblasts or osteoblastic cell lineages, whereas the first cells to colonize the implant surface are the undifferentiated MSCs. ${ }^{57}$ Curtis and Wilkinson indicate that various cell types respond differently to similar nanostructures. ${ }^{58}$ Only a few publications focus on the function of ASCs in nanotopographies. ${ }^{59}$ To our knowledge, this is the first study on the viability, proliferation, and differentiation potential of human ASCs from the subcutaneous fat tissue on nanoporous Ti. There are controversies about the content of the culture medium. Some authors postulate the use of very basic culture medium without osteogenic factors to investigate the osteogenic potential only of the nanoporous environment. ${ }^{49}$ However, we decided to supplement the culture medium with osteogenic factors because the cell population used in this study was a heterogeneous mixture of diverse cell types in different developmental phases.

A series of studies has indicated that nanotopography stimulates the adhesion, growth, and osteogenic dedifferentiation of MSCs. ${ }^{60-64}$ However, there is no consensus about the optimal geometric parameters of nanostructures. ${ }^{42,54,58,65-68}$ Bauer et al postulated the negative impact of pore diameter larger than $50 \mathrm{~nm}$ on cell viability.$^{52}$ Also, Park et al observed a gradual increase in cell apoptosis with the pore diameter increasing $>50 \mathrm{~nm}$ and an almost complete loss of adhesion on $\sim 100 \mathrm{~nm}$ pores. ${ }^{53}$ On the contrary, other researchers have found that nanopores of $100 \mathrm{~nm}$ size stimulate the growth and osteogenic differentiation of cultured cells. ${ }^{58,69,70}$ In our study, we did not observe the harmful effects of pores of 80 and $108 \mathrm{~nm}$ size on cell viability. The results confirm the lack of toxicity of the nanoporous ATO and osteogenic medium human ASCs.

In this study, the BrdU cell proliferation assay revealed the best conditions for cellular proliferation on electropolished Ti samples. This observation is consistent with the theory that the intensity of adhesion and proliferation are inversely proportional to cell differentiation. ${ }^{47}$ Boyan et al reported that on rough surfaces, cells divide slower, but adhere and differentiate faster. ${ }^{70}$ Similar results were published by Zinger et al. ${ }^{46}$ Probably, the synergistic effect of nanotopography and the osteogenic factors from the medium switch cells from proliferation to differentiation at the very early stages of cell culture. The sudden decrease in cell division on day 4 is probably caused by contact inhibition in cells crowded on small Ti surface.

SEM observations confirmed the presence of a dense network of cells on the Ti samples. On nano- $\mathrm{TiO}_{2}$, the cells formed clusters of communicating cells, which is a normal phenotypic behavior of MSCs. ${ }^{52}$ It has been proven that cell shape corresponds with the direction of cell differentiation: round morphology promotes adipogenesis, whereas polygonal cells (as observed in this experiment on nanoporous samples) are more likely to undergo osteoblastic metamorphosis. ${ }^{16,71}$ The role of long cellular protrusions in osteogenesis is also postulated. Long extinctions anchor in the pores and spread on the body of the cell. Signals are transduced through the cytoskeleton to the nucleus and can modify the gene expression and cellular fate. SEM images also showed creations that might be identified as fibers of extracellular matrix and nodules of mineralization. Our results suggest that nanoniche is a favorable environment for ASCs and osteogenic differentiation. Similar findings have been published by McNamara et al, ${ }^{72}$ Frandsen et al, ${ }^{66}$ Lavenus et al,,${ }^{57}$ Brammer et al, ${ }^{73}$ Popat et al. ${ }^{51}$ Alizarin staining corroborated the superior influence of nanotopography on calcium deposition and extracellular mineralization.

The initial relatively high expression of alkaline phosphatase decreased with time probably due to the involvement of cells in more advanced differentiation processes. The downregulation of $A L P L$ expression correlated with the significant upregulation of $B G L A P$ on nano- $\mathrm{TiO}_{2}$ with pores $\sim 108 \mathrm{~nm}$, matrix calcification, and changes in cell morphology. Osteocalcin (BGLAP) is a major noncollagenous protein component of extracellular matrix of the bone tissue and is considered to be the terminal marker of osteogenic differentiation. Runx 2 is the central transcription factor required for the commitment of MSCs to the osteoblast lineage. ${ }^{74}$ Many bone-related genes, such as alkaline phosphatase, osteocalcin, osteopontin, and sialoprotein, 
are regulated by Runx $2 .{ }^{75}$ The expression of Runx 2 was significant and similar on all Ti samples at all time points. This is probably because Runx2 is activated at each stage of differentiation - from MSC, through immature progenitors, to fully functional osteoblast. $B M P 2 K$ is engaged at very early stages of osteoblastogenesis associated with the activation of Runx2, and probably, changes in its expression have not been captured in this experiment. Osterix (SP7) is a highly specific transcription factor that is essential for osteoblastogenesis. ${ }^{76}$ A significantly higher expression of $S P 7$ on nanoporous samples at the early stages of cell culture confirms the promoting properties of nano- $\mathrm{TiO}_{2}$.

It can be hypothesized that the nanotopography of $\mathrm{TiO}_{2}$ replicates the porous structure of native bone and creates a better condition for osteogenesis.

\section{Conclusion}

Based on our results, within the limitations of this study, it can be postulated that anodic nanostructured $\mathrm{TiO}_{2}$ is a safe and nontoxic biomaterial. Moreover, it can promote osteodifferentiation of human ASCs from abdominal subcutaneous fat tissue in the in vitro culture.

The findings of this study would be extremely useful in the fundamental understanding of cell biology and in the application of new modifications for biomaterials and implant design. Further in vitro and in vivo tests should be performed to assess ASC-based treatment strategies and tissue regeneration potential of implants opsonized with autologous stem cells.

\section{Acknowledgments}

The article is based on the research conducted by Katarzyna Malec for her doctoral thesis. The doctoral thesis has been presented in the form of monograph only to the committee of the Jagiellonian University Medical College and has not been published elsewhere.

\section{Disclosure}

Katarzyna Malec acknowledges support from the grant Interdisciplinary PhD Studies "Molecular sciences for medicine" (co-financed by the European Social Fund within the Human Capital Operational Program). The authors report no other conflicts of interest in this work.

\section{References}

1. Abrahamsson I, Zitzmann NU, Berglundh T, Wennerberg A, Lindhe J. Bone and soft tissue integration to titanium implants with different surface topography: an experimental study in the dog. Int J Oral Maxillofac Implants. 2001;16(3):323-332.
2. Carrel A, Burrows M. Culture In Vitro of malignant tumors. J Exp Med. 1911;12:571-575.

3. Liu H, Webster T. Nanomedicine for implants: a review of studies and necessary experimental tools. Biomaterials. 2007;28(2): 354-369.

4. Portan DV, Kroustalli AA, Deligianni DD, Papanicolaou GC. On the biocompatibility between $\mathrm{TiO} 2$ nanotubes layer and human osteoblast. J Biomed Mater Res A. 2012;100(10):2546-2553.

5. Gao J, Xu B. Applications of nanomaterials inside cells. Nanotoday. 2009;4:37-51.

6. Wojnicz R. Nanomedicine as the basis of personalised medicine. Kardiol Pol. 2011;69(10):1107-1108.

7. El-Sadik AO, El-Ansary A, Sabry SM. Nanoparticle-labeled stem cells: a novel therapeutic vehicle. Clin Pharmacol. 2010;2:9-16.

8. Webster TJ, Ergun C, Doremus RH, Siegel RW, Bizios R. Enhanced functions of osteoblasts on nanophase ceramics. Biomaterials. 2000; 21(17): 1803-1810.

9. Zwilling V, Aucouturier M, Darque-Ceretti E. Anodic oxidation of titanium and TA6V alloy in chromic media. An electrochemical approach. Electrochim Acta. 1999;45(6):921-929.

10. Gong D, Grimes CA, Varghese OK, et al. Titanium oxide nanotube arrays prepared by anodic oxidation. J Mater Res. 2001;16(12):3331-3334.

11. Vega V, Prida VM, Hernandez-Velez M, et al. Influence of anodic conditions on self-ordered growth of highly aligned titanium oxide nanopores. Nanoscale Res Lett. 2007;2:355-363.

12. Ghafar A, Chong C, Seung HY, Kum JM, Cho SO. Fabrication of complete titania nanoporous structures via electrochemical anodization of Ti. Nanoscale Res Lett. 2011;6:322.

13. Indira K, Ningshen S, Kamachi Mudali U, Rajendran N. Effect of anodization parameters on the structural morphology of titanium in fluoride containing electrolytes. Mater Charact. 2012;71:58-65.

14. Jarosz M, Pawlik A, Kapusta-Kołodziej J, Jaskuła M, Sułka G. Effect of the previous usage of electrolyte on growth of anodic titanium dioxide (ATO) in a glycerol-based electrolyte. Electrochim Acta. 2014;136: 412-421.

15. Macak JM, Schmuki P. Anodic growth of self-organized anodic $\mathrm{TiO} 2$ nanotubes in viscous electrolytes. Electrochim Acta. 2006;52(3): 1258-1264.

16. Lavenus S, Ricquier JC, Louarn G, Layrolle P. Cell interaction with nanopatterned implants. Nanomedicine. 2010;5(6):937-947.

17. Bunnell BA, Flaat M, Gagliardi C, Patel B, Ripoli C. Adipose-derived stem cells: isolation, expansion and differentiation. Methods. 2008; 45(2):115-120.

18. De Ugarte DA, Morizono K, Elbarbary A, et al. Comparison of multilineage cells from human adipose tissue and bone marrow. Cells Tissues Organs. 2003;174(3):101-109.

19. Halvorsen YC, Wilkinson WO, Gimble JM. Adipose-derived stromal cells-their utility and potential in bone formation. Int $J$ Obes Relat Metab Disord. 2000;24(Suppl 4):41-44.

20. Zuk PA, Zhu M, Mizuno H, et al. Multilineage cells from human adipose tissue: implications for cell-based therapies. Tissue Eng. 2001; 7(2):211-226.

21. Zuk PA, Zhu M, Ashjian P, et al. Human adipose tissue is a source of multipotent stem cells. Mol Biol Cell. 2002;13(12):4279-4295.

22. Hattori H, Sato M, Masuoka K, et al. Osteogenic potential of human adipose tissue-derived stromal cells as an alternative stem cell source. Cells Tissues Organs. 2004;178(1):2-12.

23. Sułka G, Kapusta-Kołodziej J, Brzózka A, Jaskuła M. Fabrication of nanoporous $\mathrm{TiO} 2$ by electrochemical anodization. Electrochim Acta. 2010;55(14):4359-4367.

24. Kapusta-Kolodziej J, Tynkevych O, Pawlik A, Jarosz M, Mech J, Sułka G. Electrochemical growth of porous titanium dioxide in a glicerol-based electrolyte at different temperatures. Electrochim Acta. 2014;144:127-135.

25. Hauner H, Schmid P, Pfeiffer EF. Glucocorticoids and insulin promote the differentiation of human adipocyte precursor cells into fat cells. J Clin Endocrinol Metab. 1987;64(4):832-835. 
26. MacDougald OA. Methods in Enzymology. Methods of adipose tissue biology, part B. Preface. Methods Enzymol. 2014;538:12-14.

27. Girolamo L, Sartori MF, Albisetti W, Brini AT. Osteogenic differentiation of human adipose-derived stem cells: comparison of two different inductive media. J Tissue Eng Regen Med. 2007;1(2):154-157.

28. Nachlas MM, Margulies SI, Goldberg JD, Seligman AM. The determination of lactic dehydrogenase with tetrazolium salt. Anal Biochem. 1960;1:317-326.

29. Allen MJ, Rushton N. Use of the CytoTox 96TM assay in routine biocompatibility testing in vitro. Promega Notes. 1994;45:7-10.

30. Mullis KB. The unusual origin of the polymerase chain reaction. $S c i$ Amer. 1990;262(4):56-65.

31. Valasek MA, Repa JJ. The power of real-time PCR. Adv Physiol Educ. 2005;29(3):151-159.

32. Chomczyński P, Sacchi N. The single-step method of RNA isolation by acid guanidinium thiocyanate-phenol-chloroform extraction: twentysomething years on. Nat Protoc. 2006;1(2):581-585.

33. Livak KJ, Schmittgen TD. Analysis of relative gene expression data using real-time quantitative PCR and the 2(-Delta Delta C(T)) method Methods. 2001;25(4):402-408.

34. Liu W, Saint DA. A new quantitative method of real time reverse transcription polymerase chain reaction assay based on simulation of polymerase chain reaction kinetics. Anal Biochem. 2002;302(1): $52-59$.

35. Bialorucki C, Subramanian G, Elsaadany M, Yildirim-Ayan E. In situ osteoblast mineralization mediates post-injection mechanical properties of osteoconductive material. J Mech Behav Biomed Mater. 2014;38:143-153.

36. Lowry OH, Rosebrough NJ, Farr AL, Randall RJ. Protein measurement with the Folin phenol reagent. J Biol Chem. 1951;193(1):265-275.

37. Peterson GL. A simplification of the protein assay method of Lowry et al, which is more generally applicable. Anal Biochem. 1977;83(2): 346-356.

38. Peterson GL. Determination of Total Protein. Methods Enzymol. 1983;91:95-121.

39. Ghicov A, Schmuki P. Self-ordering electrochemistry: a review on growth and functionality of $\mathrm{TiO} 2$ nanotubes and other self-aligned $\mathrm{MOx}$ structures. Chem Commun. 2009;20:2791-2808.

40. Roy P, Berger S, Schmuki P. TiO2 nanotubes: synthesis and applications. Angew Chem Int Ed Engl. 2011;50(13):2904-2939.

41. Bauer S, Park J, Faltenbacher J, Berger S, von der Mark K, Schmuki P. Size selective behavior of mesenchymal stem cells on $\mathrm{ZrO} 2$ and $\mathrm{TiO} 2$ nanotube arrays. Integr Biol (Camb). 2009;1(8-9):525-532.

42. Huang JY, Zhang KQ, Lai YK. Fabrication, modification, and emerging applications of $\mathrm{TiO}_{2}$ nanotube arrays by electrochemical synthesis: a review. Int J Photoenergy. 2013;2013:Article ID 761971, 19 pp.

43. Hou Y, Cai K, Chen X, et al. Effects of titanium nanoparticles on adhesion, migration, proliferation and differentiation of mesenchymal stem cells. Int J Nanomedicine. 2013;8:3619-3630.

44. Park J, Bauer S, Schiegel KA, Neukam FW, von der Mark K, Schmuki P. TiO2 nanotube surfaces: $15 \mathrm{~nm}$ - an optimal length scale of surface topography for cell adhesion and differentiation. Small. 2009;5(6): 666-671.

45. Hackenberg S, Scherzed A, Technau A, Froelich K, Hagen R, Kleinsasser N. Functional responses of human adipose tissue-derived mesenchymal stem cells to metal oxide nanoparticles in vitro. $J$ Biomed Nanotechnol. 2013;9(1):86-95.

46. Zinger O, Anselme K, Denzer A, et al. Time-dependent morphology and adhesion of osteoblastic cells on titanium model surfaces featuring scale-resolved topography. Biomaterials. 2004;25(14): 2695-2711.

47. Oh S, Daraio C, Chen LH, Pisanic TR, Finones RR, Jin S. Significantly accelerated osteoblasts cell growth on aligned $\mathrm{TiO} 2$ nanotubes. $J$ Biomater Res A. 2006;78(1):97-103.

48. Le Guehennec L, Martin F, Lopez-Heredia MS, et al. Osteoblastic cell behaviour on nanostructured metal implants. Nanomedicine (Lond). 2008;3:61-71.
49. Oh S, Brammer KS, Li YS, et al. Stem cell fate dictated solely by altered nanotube dimension. Proc Natl Acad Sci U S A. 2009;106: 2130-2135.

50. De Oliveira PT, Zalzal SF, Beloti MM, Rosa AL, Nanci A. Enhancement of in vitro osteogenesis on titanium by chemically produced nanotopography. J Biomed Mater Res A. 2007;80(3):554-564.

51. Popat KC, Leoni L, Grimes CA, Desai TA. Influence of engineered titania nanotubular surfaces on bone cells. Biomaterials. 2007;28(21): 3188-3197.

52. Bauer S, Park J, von der Mark K, Schmuki P. Improved attachement of mesenchymal stem cells on super-hydrophobic TiO2 nanotubes. Acta Biomater. 2008;4(5):1576-1582.

53. Park J, Bauer S, von der Mark K, Schmuki P. Nanosize and vitality: TiO2 nanotube diameter directs cell fate. Nano Lett. 2007;7(6):1686-1691.

54. Pittrof A, Park J, Bauer S, Schmuki P. ECM spreading behavior on micropatterned TiO2 nanotubes surfaces. Acta Biomater. 2012;8(7): 2639-2647.

55. Rebelatto CK, Aguiar AM, Moretão MP, et al. Dissimilar differentiation of mesenchymal stem cells from bone marrow, umbilical cord blood, and adipose tissue. Exp Biol Med (Maywood). 2008;233(7):901-913.

56. Zhang L, Webster T. Nanotechnology and nanomaterials: Promises for improved tissue regeneration. Nanotoday. 2009;4(1):66-80.

57. Lavenus S, Berreur M, Trichet V, Pilet P, Louarn G, Layrolle P. Adhesion and osteogenic differentiation of human mesenchymal stem cells on titanium nanopores. Eur Cell Mater. 2011;22:84-96.

58. Curtis A, Wilkinson C. Topographical control of cells. Biomaterials. 1997;18(24):1573-1583.

59. Lv L, Liu Y, Zhang P, et al. The nanoscale geometry of TiO2 nanotubes influences the osteogenic differentiation of human adipose-derived stem cells by modulating H3K4 trimethylation. Biomaterials. 2015;39: 193-205.

60. Von Wilmowsky $\mathrm{C}$, Bauer S, Lutz R, et al. In vivo evaluation of anodic TiO2 nanotubes: an experimental study in the pig. J Biomed Mater Res B Appl Biomater. 2009;89(1):165-171.

61. Bjursten LM, Rasmusson L, Oh S, Smith GC, Brammer KS, Jin S. Titianium dioxide nanotubes enhance bone bonding in vivo. J Biomed Mater Res A. 2010;92(3):1218-1224.

62. Li X, Liu H, Niu X, et al. The use of carbon nanotubes to induce osteogenic differentiation of human adipose-derived MSCs in vitro and ectopic bone formation in vivo. Biomaterials. 2012;33(19):4818-4827.

63. Minagar S, Wang J, Berndt CC, Ivanova EP, Wen C. Cell response of anodized nanotubes on titanium and titanium alloys. J Biomed Mater Res A. 2013;101(9):2726-2739.

64. Yao C, Slamovich EB, Webster TJ. Enhanced osteoblast functions on anodized titanium with nanotube-like structures. J Biomed Mater Res A. 2008;85(1):157-166.

65. Chiang CY, Chiou SH, Yang WE, et al. Formation of TiO2 nanonetwork on titanium surface increase the human cell growth. Den Mater. 2009;25(8):1022-1029.

66. Frandsen CJ, Brammer KS, Jin S. Variations to the nanotube surface for bone regeneration. Int J Biomater. 2013;2013:513680.

67. Hosseinkhani H, Hosseinkhani M, Tian F, Kobayashi H, Tabata Y. Osteogenic differentiation of mesenchymal stem cells in selfassembled peptide-amphiphile nanofibres. Biomaterials. 2006;27(22): 4079-4086.

68. Dulgar-Tulloch AJ, Bizios R, Siegel RW. Human mesenchymal stem cell adhesion and proliferation in response to ceramic chemistry and nanoscale topography. J Biomed Mater Res A. 2009;90(2):586-594.

69. Wang LN, Jin M, Zheng Y, Guan Y, lu X, Luo JL. Nanotubular surface modification of metallic implants via electrochemical anodization technique. Int J Nanomedicine. 2014;9:4421-4435.

70. Boyan BD, Lohmann CH, Dean DD, Sylvia VL, Cochran DL, Schwartz Z. Mechanisms involved in osteoblasts response to implant surface morphology. Ann Rev Mater Res. 2001;31:357-371.

71. Kilian KA, Bugarija B, Lahn BT, Mrksich M. Geometric cues for directing the differentiation of mesenchymal stem cells. Proc Natl Acad Sci U S A. 2010;107(11):4872-4877. 
72. McNamara LE, Sjostrom T, Seunarine K, Meek RD, Su B, Dalby MJ. Investigation of the limits of nanoscale filopodia interactions. J Tissue Eng. 2014;5:2041731414536177.

73. Brammer KS, Seunghan O, Cobb CJ, Bjursten LM, van der Heyde H, Jin S. Improved bone-forming functionality on diameter-controlled TiO2 nanotube surfaces. Acta Biomater. 2009;5(8):3215-3223.

74. Komori T. Regulation of osteoblast differentiation by Runx2. Adv Exp Med Biol. 2010;658:43-49.
75. Liu JC, Lengner CJ, Guar T, et al. Runx2 protein expression utilizes the Runx2 P1 promoter to establish osteoprogenitor cell number for normal bone formation. J Biol Chem. 2011;286(34):30057-30070.

76. Zhu F, Friedman MS, Luo W, Woolf P, Hankenson KD. The transcription factor osterix (SP7) regulates BMP6-induced human osteoblast differentiation. J Cell Physiol. 2012;227(6):2677-2685.

\section{Publish your work in this journal}

The International Journal of Nanomedicine is an international, peerreviewed journal focusing on the application of nanotechnology in diagnostics, therapeutics, and drug delivery systems throughout the biomedical field. This journal is indexed on PubMed Central, MedLine, CAS, SciSearch $®$, Current Contents ${ }^{\circledR} /$ Clinical Medicine,
Journal Citation Reports/Science Edition, EMBase, Scopus and the Elsevier Bibliographic databases. The manuscript management system is completely online and includes a very quick and fair peer-review system, which is all easy to use. Visit http://www.dovepress.com/ testimonials.php to read real quotes from published authors. 